\title{
Evaluating the Effects of Environmental Renovation Projects on Behavioral Pattern of Users in Space
}

\author{
N. Barati, N. Falah, and M. Piroozgar
}

\begin{abstract}
Sidewalks are an indispensable part of urban public space, through utilization of which, identifiable behavioral patterns emerge, interwoven relationships among individuals via social activities. However, in spite of their enormous contribution to urban life, no attention is paid to their renovation designs. Therefore, it is crucial to evaluate urban designs and plans base on none-abstracted methods. Sepah Street (the oldest designed street in Iran) in Qazvin, during 2009-2011, went through some basic changes in its sidewalks by implementing the renovation project. It was expected that these changes would make pedestrians pause for a while within the space and hence positively affect the quality of the behavioral patterns and social life of the city. This paper aims at an approach-based comparison of behavioral patterns before and after implementation of the project (2007-2012) using proportional-qualitative methodology (direct observation, semi-organized interview) and behavioral patterns indices determination. The effect of the design on the amount, type and formations of users' behavioral patterns is determined and evaluated.
\end{abstract}

Index Terms-Sidewalk, behavioral pattern, renovation, qazvin sepah street.

\section{INTRODUCTION}

Urban designs' evaluation in the stage of design and post implementation (in two short-and long-term stages)is one of the critical steps taken by designers to evaluate all the related aspects, improve projects' quality to achieve the predetermined objectives and fulfilling the users' needs. Various factor in users' behavior, affect the environment which demonstrates the level of citizens' satisfaction. The interchangeable effects of human behaviors and urban surroundings a determinative factor in shaping people's satisfaction and subsequently contribute towards formation of the interacting spaces. Renovations of the sidewalk on Sepah Street have been merely done base on abstract ideabasis of the designers. Hitherto this project has attracted many debates and critics who question the success of such projects. The necessary information was collected using library and field studies, observation techniques and semiorganized interview.

This research looks for responses to these questions:

- How people reacted to the changes in Sepah Street?

- Have the changes in Sepah street side walk made

Manuscript received November 10, 2013; revised February 11, 2014 This work was supported in part by Department of urban planning of Imam Khomeini International University of Qazvin, Iran.

The authors are with the Department of Urban Planning, Imam Khomeini International University of Qazvin, Iran (E-mail: Naser.Barati2012@yahoo.com, falah_nadia1988@yahoo.com, MPirouzgar88@yahoo.com). any effective reformation in people's behaviors?

To answer these questions, the following hypotheses are provided:

- Changes in Sepah Street sidewalk have not changed people's behaviors for the better.

- These changes did not have positive feedback and led to the decrease in social interactions and people's presence.

\section{A. Research Background}

Professor Donald A ppleyard is recognized as the founder of behavioral-visual studies that carried out the first visual-mental study in civic scale with the help of Linch and John Mayer. He published his study titled "The View from the Road"in1961.This study put its emphasis on visual recognition aspects but did not focus on the behavior of the space users. About 10 years later, William Michelson studied the behavioral aspects of the space users to achieve a better recognition of behavioral patterns of people in various time periods (on daily, weekly and monthly basis). In Iran, Dr. Bahraini used the same method to study the behaviors of pedestrians in some squares in Tehran in 1977.

\section{BASIC CONCEPTS AND THEORETICAL PRINCIPALS IN PHRASEOLOGY BEHAVIOR AND BEHAVIORAL NECESSITIES}

Human behavior is the result of personal needs, motivations, environmental capabilities, and person's mental image from the world which reflects his recognition. Behavioral necessities are a function of activities, time and place which need the following factors: an activity can be done through various ways, a special part of the environment that is in proportion to the behavior, connection between the two above-mentioned factors and a specific period of time period [1].

\section{A. Human Behavior and Environmental Recognition}

People's behavior is the result of recognition and

Understanding processes that come from motivations and other internal and external factors affecting environmental and personal aspects. Human behavioral analysis of an environment can be the basis of recognition, understanding, and effectiveness of a space that leads to a specific environmental behavior. [2] These patterns eventually complete human recognition.

\section{B. The Features of Behavior}

Behavior contains features that separate it from activity including visibility; any factor that is used for answering a need, is bound to have a special from that makes it visible. In designs, we encounter behaviors not activities. Behavior 
changeability: Deterministic believe that the environment determines people's behavior while probabilistic believe in the probability of human behavior [3]. Passing human mental space: human relationship with the environment passes through a filter called "mental space". Despite the activities, human behaviors must pass through this space.

Social expectancies: people of different environments have different expectations. Every special environment has its own special behaviors. The effect of space on behavior: space as a part of the environment can affect behavior and has controlling role, i.e. encourages some behaviors and discourages the others. In the case of activities, space can only provide the possibility or impossibility of an activity [4]. Behavior in generally controlled in two ways:

Induction Behavior: Space can induce particular behaviors. By preparing an appropriate space, people follow those behavioral patterns automatically.

Physical setting: Some behavioral patterns, impose new social roles to their settlers, encourage or discourage.

Omit behavior: If an appropriate space is not provided for people, they will not be encouraged to take up the aforementioned behavior, subsequently leading to its omission from urban space.

The effect of behavior on the quality of space: Through encouraging some behaviors or preventing some others, it is possible to develop special feeling in people. Simultaneously, time, behavior and personal experiences are changed by the environment [5].

\section{Different Types of Behavioral Patterns}

Motivational-recognition-understanding patterns: emphasizes on environment recognition, emotional feelings, the environmental concepts and recognition reacting to the environment.

Human behavioral patterns: emphasizes on mutual effect of environment and people and quality of people's interaction with the environment. Behaviors must be defined in its environmental context. These two are interrelated so closely that renders them inseparable. The best is to analyze the relationship between the people and environment in the ecological pattern, in which there is a mutual effect between environment and people [6]. Apple yard recognizes four ways to discover the factors of the environment including having recognizable form, seeing them while people are moving in city, their roles as a background for activities, the importance of buildings in the society, in the case of which, Rapp a port believes that there are five main aspects to form behavioral spaces. He states the main factors of recognizing behavioral patterns in the environment as following:

- How the activities;

- The construction of the society (social-cultural factor)

- The roles of genders and age group

- The process of social relationships [7].

\section{Behavioral Environment Description}

The environment is referred to as," the combined form of all things that encompass it and has the power and potential to communicate with the man".

Although the entire information is not accessible for people, behavioral environment consists of natural and artificial factors or a combination of both. Kurt Kafka has divided environment in 3parts based on how it is seen:

Physical environment: geographical factors and environmental element;

Social environment: institution, people and the users;

Psychological environment: all behaviors are analyzed in proportion to architectural-physical aspects or environmental motives .The description of the behavioral environment entails the following five variations and measurements: the measurement of physical dimension, material dimension, variety and numbers of available accessories in a space, place and space traits description, behaviors normally seen in the space and the condition of organization and social environment [8].

\section{BASIC CONCEPTS IN URBAN SPACES}

Public and open spaces in cities are as a common background that provides the possibility of human presence as the main user. Political and demonstrative behavior; social interaction; relationships act as the stage for social recognition, personal progress and information sharing process. Street can be analyzed according to visual mobility or non-mobility, being surrounded or not, being long or not, being wide, narrow or curved, scale, proportion, and pace, in relation to other street and squares. The identity of streets can be changed in a way that makes them more or less vibrant and durable [9].

Pedestrian way is a kind of separate and isolated part of the street on which the entry of all forms of vehicles is prohibited. Pedestrian way includes the whole width of the way [10].

Pedestrians include all people except babies and handicapped. Although babies and handicapped are excluded from pedestrians, they utilize the sidewalks too. Space users mean all who use space directly or indirectly and potentially have the ability to reform the space. Pedestrians include passer byes, residents, shop keepers, etc. Pavement patterns can improve street's linear aspect and make visual steps slow while emphasizes on its character as a route, by providing a directing sense and movement pattern, or visual non-mobility and waiting in the space, making it more beautiful and provide the city with qualities and scale for the city view. Because, the commuting pattern can reflect the way streets are surfaced. While brick or stone patterns are used to indicate the walking area in the sidewalks, the asphalted areas are dedicated to vehicles. Urban furniture refers to a wide variety of devices, objects, equipment and elements which relocated in every open urban space and are used by everyone. Gil Space suggests a general rule for organizing urban furniture which can be used in the urban furniture position evaluation: a design with the purpose of using the least furniture for street, making all the elements unite as much as possible, deletion of unnecessary elements of urban furniture in order to improve quality of the environment, make the space look creative or unique and prevention of sidewalks and streets joining each other [11]. Accordingly, principal rules in designing urban furniture are divided in two categories: physical(form, color, texture, joints, ingredients)and nonphysical(going with the environment, being safe, 
availability, few components, ease of production, durability, being vandal proof, usability for different age groups, and being economical, with strong construction).

\section{ENVIRONMENT EVALUATION}

Designers draw this conclusion that, people have not always used environments in a predictable way. Sometimes, this environment does not match their life style and sometimes provides them with opportunities that they have never thought of having before. It makes sense to say that the designed environments must be evaluated periodically. Evaluation of the environmental function must be done before, during and after their construction in a longer period of time.

Environment during design: The initial phases of reviewing the environment during the design period include data gathering to determine user needs and the extent of their preference. To evaluate the suggested design, it is compared with users' needs (through simulation and model evaluation).

Environment personal evaluation after design: before the process, environment and the user are permitted to match with one another which requires their capabilities evaluation according to what has been collected, followed by the evaluation of the unpredicted results.

Long-term environment evaluation: through short-term consequences evaluation, we cannot predict longer ones. Therefore, the following activities are necessary during design:

- Experimental analysis of environment and behavior relationships (finding behavioral patterns, causes of satisfaction and dissatisfaction of people from environment);

- Computer model simulation and modeling the relationships of these factors;

- Real-design of environment;

- Consequences evaluation

5-Permanent evaluation and analysis in all stages are necessary to optimize the gradual construction of the environment, during the period.

The last step: Permanent change and evaluation of environment and its consequences, because the relationship between environment and human behavior is a dynamic process. [12]

\section{A. Criticizing Designs and Environment Evaluation}

- Design-employer relationship (social vacuum): the difference between costumer and design's value: the relationship between architect and investor but not the user;

- The concept of function: misunderstanding the concept of function and acting nonchalant towards reaching goals (identity, security, etc.)in man-made environment;[13]

- Human-environment relationship: believing in architectural determination and the existence of the relationship between human and environment (bodylike models, role models, relationship model);

- The nature of theoretical principals: The lack of organized theoretical principals: in environmental design.

\section{B. Behavior Interpretation Method}

Nowadays, in field of social sciences, although observation-based interpretations need more time, capability and accuracy for analysis, however, they are more reliable compared to the other common methods like questionnaires and interviews. This is due to lesser interference in behavior natural process; because these methods are based on the expert' sown observations and follow special directions. On the other hand, people are only required to answer provided questions that make them unreliable due to the inconsistency of their values and norms. The following factors must be specially noticed in observations:

- Personal and group behaviors;

- Behaviors in different time-periods;

- Observing behavioral changes.

\section{Phraseology Indices}

According to the studies and cases in the literature (Theories of Airmen, Rapp port, Carmona, Lang, Krick, etc.) of internationally related projects, this domain in studies, through a critical look along with the experts' opinion, city authorities, residents and the following indices, were determined as effective ones in the process of determination or/and changes of users' behavioral patterns:

Time, context, place, physical and natural available factors, people's age group, gender, people's walking position, and people's mental situation.

Whatever is seen in regards to any kind of behavior in the environment is a part of the factors that are mentioned here. It is expected that, after implementing this project, any behavioral pattern changes will be due to the change of one or more factors mentioned.

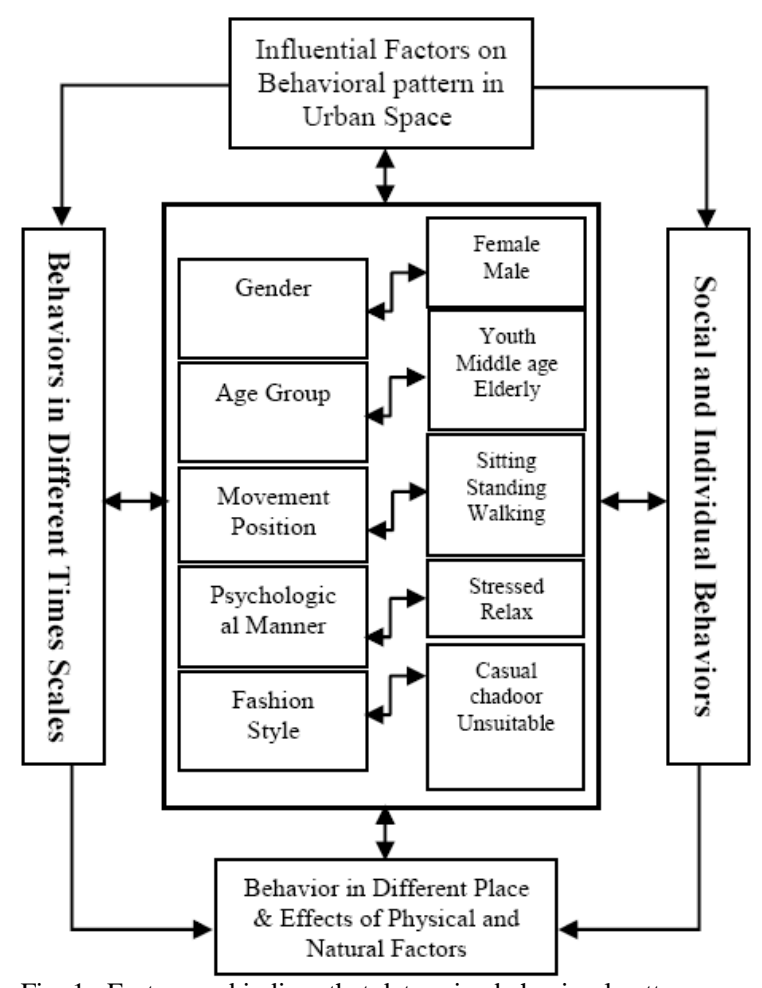

Fig. 1. Factors and indices that determine behavioral patterns. source: writers. 


\section{HYPOTHESIS TEST}

First Method: Observation: Gathering information related to factors in Fig. 1 that determine pedestrians' behavioral patterns through a four-step behavior interpretation process:

- Observation (directly or indirectly by camera or camcorder) during morning (7-9a.m.), noon (11-13 p.m.) and evening (17-19 p.m.) in the area between the market and congregation mosque in 2007(before the project) to 2012(after the project). Both were done in October for a week;

- Recording observations;

- Analyzing given information;

- Implementing analytical results in the project.

Behavioral Plan Preparation: The process of assimilation was based on Proshnaski method: direct environment analysis, environmental understanding with the help of

picture (table, charted.) and testing environmental situation through imagination and based on responses.

After filming and taking picture in ten- minutes time period and revising films, turning them into one-Minutes time period, a behavioral plan was prepared for every one of them to show the number of people in those places in which the behaviors were observed through overlapping the plans. A final plan was prepared to determine the behaviors related to every index and according to every single time period. In the end, due the impact of natural/artificial factors on the domain and lighting the space and barriers were compared with those of before.

The second method: Free interview: Gathering information through free interview. As the second step, based on the information given by observations, semiorganized interview of the space users were applied in order to evaluate the final situation and the function of the plan, its impact on people's behavior and matching the result of observations with it.
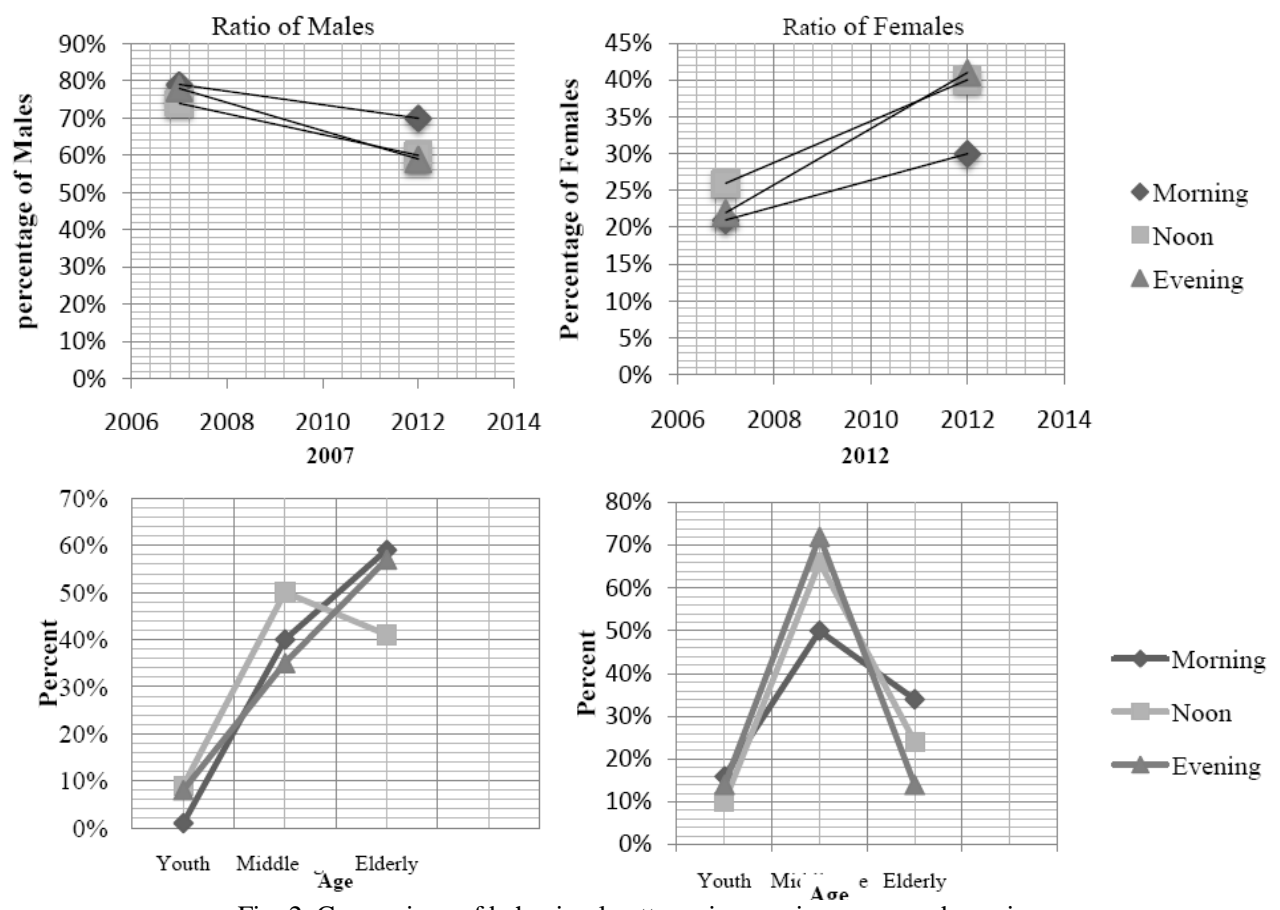

Fig. 2. Comparison of behavioral patterns in morning, noon and evening source: writers: 2007-2012.

\section{A. Case Study (Sepah Street)}

Sepah Street, the first street in Iran (which was registered in the list of Iran's national historical places), was built in Safavieh era and is known as a designed path. By the time that railway reached Qazvin, this street ended in railway station. Sepah Street mostly encompasses commercial functions (in regional, local and functional levels) which do not seem appropriate due to the outstanding identity of Sepah Street in Qazvin. The case study is restricted to the area between Atigh mosque and Sepah square.

\section{B. An Introduction to Sepah Street Plan}

Sepah street renovation is one of the principal projects that were implemented in Qazvin for the purpose of developing tourism and introducing Qazvin as a cultural and historic city along with its ancient civilization. The renovation process included the following steps:

Step 1: Paving and constructing the premises of the mosque; repairing the sidewalk and the furniture;

Step 2: Paving with cobblestone;

Step 3: An analysis over the position of the street compared to those of other street, along with determining whether or not the street is for pedestrians or cars;

Step 4: Paving and lighting the street.

Accordingly, the following predicted activities will be put into implementation in order to:

- Omitting the accessories from the main body to reveal the real view, and match color and form of the bodies;

- Paving the middle part with cobblestone;

- Covering gutters;

- Preparation of the functions and green space arrangement plan.

C. An Evaluation and Analysis over the Studying Indices: Psychological Manner of Space Users

Psychological manner refers to the behavioral feedback 
of people and comes from the environment impact on people or from other personal issues which show people's willingness to attend, stay in the space and also their feelings about the environment in which the spaces are located. The psychological manner of the space users after implementing the project did not change significantly.

Gender: To evaluate a project, it should be considered that if appropriate situation is provided for longer attendance for both genders.

Movement Position: How people use the space? What possibilities are provided for people and how people's objectives to attend the place are related to their movement position?

Age Group of the Space Users: What age group this space was suitable for before implementing the project and has this project succeeded to attract other age groups?

Fashion Styles of the Space Users: What social class use this space? Are the changes considerable compare to the past? Does this project that initially aimed at attracting more visitors to the place, lead to the attendance of different social classes from other areas of the city.

Table I and Fig. 2 compare these indices time period divisions.

Evaluation of Urban Furniture: Elements added to the space must be evaluated, because all of them tend to have impact on the behavior and attendance of the not compatible with local and natural and historic features as well as the needs of the people.

Furthermore, these elements led to the entrance of some cyclists and drivers to the sidewalk and made the sidewalk less secure for pedestrians.

Light and lighting: Furniture is the key element for attracting people during day and night and also dynamism in civic environment. The street lighting is not enough, without the light coming from the nearby stores.

\section{Summary of Behavioral Patterns Situation and Their Changes}

Through mixing the plans of a two-year period of study and in 3 time period divisions, the following changes are significance.

\section{E. Summary of Observations}

- Reduction of the number of people in civic spaces (there are seasonal workers in the morning);

- Increase of women attendance during the day, especially in the evening, shows the space security;

- Increase of visitors in standing position and decrease in sitting position shows the willingness of people to wait and the absence of an appropriate space in the area

Increase of middle-aged people's attendance in the space and a dramatic decrease in the number of elderlies, especially in the evening shows that this space in not an appropriate one for elderlies and their needs. On the other hand, this space cannot adequately fulfill the needs of children and teenagers, although presently the situation has somewhat improved.

- There was no change in the social class of users after implementing the project;

- After renovating the area around the mosque, the place is secure enough for women to attend. Pedestrians $(65 \%$ male and $35 \%$ female) who were 23 men and 13 women.

- Although there is not enough security for pedestrians due to the passing cars, and those cars and motorcycles that blatantly ignore the law and use the sidewalk, contribute a great deal in deteriorating the existing situation.

\section{F. Interview}

A complete view of people's behaviors cannot be given by single observation. This is why in this research; interview was used as a complementary method. In this case, after observations, regarding to the results, some questions were asked from users in form of semi-open interview. Statistical community in this step includes all users of Sepah Street such as shopkeepers, pedestrians, etc. The interviews were conducted on 50 people, including 35 pedestrians and 15 shopkeepers. Table II shows the main result of the interview.

TABLE I: COMPARISON OF BEHAVIORAL PATTERNS INDICES BEFORE,

\begin{tabular}{|c|c|c|c|c|c|c|}
\hline \multirow{2}{*}{$\begin{array}{c}\text { Time } \\
\text { Movement } \\
\text { Position }\end{array}$} & \multicolumn{2}{|c|}{$\begin{array}{c}\mathbf{7 - 9} \\
\text { (Morning) }\end{array}$} & \multicolumn{2}{c|}{$\begin{array}{c}\text { 11-13 } \\
\text { (Noon) }\end{array}$} & \multicolumn{2}{c|}{$\begin{array}{c}\text { 17-19 } \\
\text { (Evening) }\end{array}$} \\
\cline { 2 - 7 } & $\mathbf{2 0 0 7}$ & $\mathbf{2 0 1 2}$ & $\mathbf{2 0 0 7}$ & $\mathbf{2 0 1 2}$ & $\mathbf{2 0 0 7}$ & $\mathbf{2 0 1 2}$ \\
\hline Sited & $32 \%$ & $5 \%$ & $57 \%$ & $27 \%$ & $24 \%$ & $4 \%$ \\
\hline Standing & $26 \%$ & $60 \%$ & $28 \%$ & $46 \%$ & $22 \%$ & $30 \%$ \\
\hline Mobility & $42 \%$ & $35 \%$ & $14 \%$ & $27 \%$ & $4 \%$ & $66 \%$ \\
\hline Total & 100 & 100 & 100 & 100 & 100 & 100 \\
\hline
\end{tabular}

\begin{tabular}{|c|c|c|c|c|c|c|}
\hline \multirow{2}{*}{$\begin{array}{c}\text { Time } \\
\begin{array}{c}\text { Psychological } \\
\text { Manner }\end{array}\end{array}$} & \multicolumn{2}{|c|}{$\begin{array}{c}\mathbf{7 - 9} \\
\text { (Morning) }\end{array}$} & \multicolumn{2}{c|}{$\begin{array}{c}\text { 11-13 } \\
\text { (Noon) }\end{array}$} & \multicolumn{2}{c|}{$\begin{array}{c}\text { 17-19 } \\
\text { (Evening) }\end{array}$} \\
\cline { 2 - 7 } & $\mathbf{2 0 0 7}$ & $\mathbf{2 0 1 2}$ & $\mathbf{2 0 0 7}$ & $\mathbf{2 0 1 2}$ & $\mathbf{2 0 0 7}$ & $\mathbf{2 0 1 2}$ \\
\hline $\begin{array}{c}\text { Relax People } \\
\text { Stressed } \\
\text { People }\end{array}$ & $36 \%$ & $60 \%$ & $62 \%$ & $77 \%$ & $66 \%$ & $86 \%$ \\
\hline Total & 100 & 100 & 100 & 100 & 100 & 100 \\
\hline
\end{tabular}

\begin{tabular}{|r|c|c|c|c|c|c|}
\hline \multirow{2}{*}{ Time } & \multicolumn{2}{|c|}{$\begin{array}{c}\mathbf{7 - 9} \\
\text { (Morning) }\end{array}$} & \multicolumn{2}{c|}{$\begin{array}{c}\text { 11-13 } \\
\text { (Noon) }\end{array}$} & \multicolumn{2}{c|}{$\begin{array}{c}\text { 17-19 } \\
\text { (Evening) }\end{array}$} \\
\cline { 2 - 7 } & $\mathbf{2 0 0 7}$ & $\mathbf{2 0 1 2}$ & $\mathbf{2 0 0 7}$ & $\mathbf{2 0 1 2}$ & $\mathbf{2 0 0 7}$ & $\mathbf{2 0 1 2}$ \\
\hline Female & $21 \%$ & $30 \%$ & $26 \%$ & $40 \%$ & $22 \%$ & $41 \%$ \\
\hline Male & $79 \%$ & $70 \%$ & $74 \%$ & $60 \%$ & $78 \%$ & $59 \%$ \\
\hline Total & 100 & 100 & 100 & 100 & 100 & 100 \\
\hline
\end{tabular}

\begin{tabular}{|c|c|c|c|c|c|c|}
\hline Time & \multicolumn{2}{|c|}{$\begin{array}{c}7-9 \\
\text { (Morning) } \\
\end{array}$} & \multicolumn{2}{|c|}{$\begin{array}{c}\text { 11-13 } \\
\text { (Noon) } \\
\end{array}$} & \multicolumn{2}{|c|}{$\begin{array}{c}17-19 \\
\text { (Evening) }\end{array}$} \\
\hline $\begin{array}{c}\text { Psychological } \\
\text { Manner }\end{array}$ & 2007 & 2012 & 2007 & 2012 & 2007 & 2012 \\
\hline Relax People & $70 \%$ & $60 \%$ & $62 \%$ & $77 \%$ & $66 \%$ & $86 \%$ \\
\hline $\begin{array}{l}\text { Stressed } \\
\text { People }\end{array}$ & $36 \%$ & $40 \%$ & $38 \%$ & $23 \%$ & $34 \%$ & $16 \%$ \\
\hline Total & 100 & 100 & 100 & 100 & 100 & 100 \\
\hline
\end{tabular}




\section{G. Sampling Method}

Organized random sampling: First, there was a method of choosing a number between 0 and10 and samples were on 10people basis.

Summary of the interview: In TableII, the points given by the interviewees (shop keepers and pedestrians)are given in 5 general categories that can be used as the main factors to analyze people's viewpoints about the plan and the plan itself. Final Summary and Conclusion: Due to some quick changes, Sepah Street's appearance was changed dramatically which affected the people's behavior.

Table III shows the summary of any merits and demerits of the plan and an evaluation about its function on people's behaviors.

TABLE II: MAIN RESULTS OF THE INTERVIEW

\begin{tabular}{|c|c|c|c|c|c|c|c|c|}
\hline & בֶב & $\begin{array}{c}\text { In your } \\
\text { opinion, did these } \\
\text { changes have a } \\
\text { positive impact on } \\
\text { people's behavior } \\
\text { or not? }\end{array}$ & $\begin{array}{c}\text { In your } \\
\text { opinion, were } \\
\text { these changes } \\
\text { more effective in } \\
\text { using the space } \\
\text { or less? }\end{array}$ & $\begin{array}{c}\text { The best } \\
\text { suggestion for } \\
\text { the current space } \\
\text { situation }\end{array}$ & $\begin{array}{c}\text { The most } \\
\text { important } \\
\text { behavioral } \\
\text { changes in space }\end{array}$ & $\begin{array}{c}\text { The most } \\
\text { important } \\
\text { functional } \\
\text { change in space }\end{array}$ & $\begin{array}{l}\text { The goal of } \\
\text { these changes }\end{array}$ & $\begin{array}{l}\text { The most } \\
\text { important } \\
\text { physical } \\
\text { change in } \\
\text { space }\end{array}$ \\
\hline \multirow{2}{*}{ 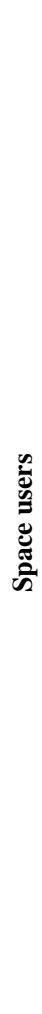 } & 菢 & $\begin{array}{l}\text { Positive } \\
\text {-more woman's } \\
\text { attend } \\
\text {-more security } \\
\text {-taking } \\
\text { away the idle } \\
\text { wanderers and } \\
\text { drug-addicted } \\
\text { people }\end{array}$ & $\begin{array}{l}\quad \text {-yes } \\
\quad \text { with more } \\
\text { women's } \\
\text { attendance }\end{array}$ & $\begin{array}{l}\text {-Running } \\
\text { water in the street } \\
\text { floods into the } \\
\text { sidewalk } \\
\text {-using } \\
\text { inappropriate } \\
\text { materials for } \\
\text { construction } \\
\text {-functional } \\
\text { changes in the } \\
\text { plan's area }\end{array}$ & $\begin{array}{l}\text {-willingness } \\
\text { for more } \\
\text { attendance in the } \\
\text { area faster-paced } \\
\text { pedestrians due to } \\
\text { being afraid of the } \\
\text { slippery floor } \\
\text {-no difference } \\
\text { in the social class } \\
\text { of the users } \\
\text {-lower number } \\
\text { of elderlies }\end{array}$ & $\begin{array}{l}\text {-Cars on the } \\
\text { sidewalk that } \\
\text { makes it less } \\
\text { secure } \\
\text {-prevents } \\
\text { elderlies to come } \\
\text { to the mosque } \\
\text {-Loitering of } \\
\text { seasonal workers } \\
\text { in the morning }\end{array}$ & $\begin{array}{l}\quad \text {-Taking } \\
\text { away drug- } \\
\text { addicted } \\
\text { people from } \\
\text { the mosque } \\
\text { area } \\
\text {-providing } \\
\text { better security - } \\
\quad \text {-more } \\
\text { women } \\
\text { attendance - }\end{array}$ & $\begin{array}{l}\text { Widening } \\
\text { sidewalks }\end{array}$ \\
\hline & $\frac{n}{\frac{0}{2}}$ & $\begin{array}{l}\quad \text { Negative } \\
\text {-low willingness } \\
\text { for shopping and } \\
\text { narrowing the } \\
\text { street } \\
\quad \text { lower } \\
\text { safety/more } \\
\text { slippery floor }\end{array}$ & $\begin{array}{l}\quad \text {-yes } \\
\text { with more } \\
\text { women's } \\
\text { attendance }\end{array}$ & $\begin{array}{l}\text {-Winding the } \\
\text { street } \\
\text {-Constructing } \\
\text { situation parking } \\
\text { space } \\
\text {-Changing the } \\
\text { function of } \\
\text { surrounding areas }\end{array}$ & $\begin{array}{l}\text {-A decrease in } \\
\text { the number of } \\
\text { people from other } \\
\text { parts of the city } \\
\text { for the purpose of } \\
\text { shopping } \\
\text {-an increase in } \\
\text { the time of } \\
\text { standing in this } \\
\text { area } \\
\text {-more people } \\
\text { fall down on the } \\
\text { ground } \\
\text {-cars move } \\
\text { more slowly }\end{array}$ & $\begin{array}{l}\text { Lengthening } \\
\text { the time of the } \\
\text { project } \\
\text {-lack of } \\
\text { parking space } \\
\text {-making the } \\
\text { street narrower } \\
\text {-slippery floor }\end{array}$ & $\begin{array}{l}\quad \text {-Blocking } \\
\text { the street after } \\
\text { seeing this } \\
\text { project in other } \\
\text { cities } \\
\text {-more } \\
\text { woman's } \\
\text { attendance }\end{array}$ & $\begin{array}{l}\text { Widening } \\
\text { sidewalks }\end{array}$ \\
\hline
\end{tabular}

source: writers: 2007-2012

TABLE III: EVALUATION OF SEPAH RENOVATION

\begin{tabular}{|c|c|}
\hline Advantages & Disadvantages \\
\hline $\begin{array}{l}\text { 1- Slower -paced pedestrians and more enjoyable area for } \\
\text { pedestrians } \\
\text { 2- More security } \\
\text { 3- More women's attendance in the place compared to the past } \\
\text { 4- More children and teenagers attendance compared to the past } \\
\text { 5- Organizing the space and the decrease of unorganized furniture } \\
\text { compared to the past } \\
\text { 6- Environmental tidiness \& cleanliness }\end{array}$ & $\begin{array}{l}\text { 1- No woman attendance around the mosque } \\
\text { 2- Not enough space for waiting to indulge in social activities } \\
\text { 3- Lack of light in the space at night -lack of space for the needs of } \\
\text { 4- Not all social classes attend there } \\
\text { 5- Inappropriate construction materials for furniture and their } \\
\text { 6- Low security level due to slippery floor and cyclists' passage } \\
\text { 7- Unorganized furniture layout } \\
\text { 8- } \quad \text { Pile of garbage and hording stuff }\end{array}$ \\
\hline
\end{tabular}

\section{OUTCOMES OF HYPOTHESIS TEST}

According to the information given, based on the given results, the first hypothesis was confirmed. The second hypothesis women's attendance and provided a more secure space compared to the past for various age groups, especially for younger woman and children of decrease in social interaction was also confirmed (which was due to the above-mentioned reason). Note that this plan helped

Before preparing any plan, its effects on users must be 
considered, critically. As we mentioned at the beginning, the most important impact that any civic plan could have, is especially on citizens.

According to the results of the observations and interviews with the space users, based on the analysis on feedback from the users, hence their participation and Sepah Street's plan, the following results and recommendations are provided:

Space changes must be in accordance with local environmental features and users' behavior. An evaluation and recognition and specific features of the plan must be identified before any plan is set into motion. The plan should be based on a thorough analytical study and subjected to a case-based approach. For instance, inappropriate materials were used for Sepah street benches; consequently, they get cold in winters and hot in summers, leading to users' aversion.

Pedestrian's behaviors can direct the civic behaviors in a positive or negative way.

For example, before plan preparation (pre-preparation evaluation), the basic factors, i.e. users' ideals, problems and needs, must be evaluated through questionnaire distribution or interviews.

Any changes in urban space should follow a positive support is a prerequisite factor to render the plan successful.

The success of a project is heavily dependent on the level of users 'awareness and about how to use the new space.

Hence, distribution of the brochures for the purpose of providing information to the Sepah street residents, primary users and neighboring establishments, was considered a vital step to get the community involved and obtain a reliable feedback about the plan (during-preparation evaluation).

(Short-term plan evaluation after its implementation): Therefore, a framework must be set to determine the success of plan in regards to social, behavioral and consequences of the Sepah street renovation project in all stages of work as an appropriate guide for developing the plan, successfully.

Inappropriate furniture distribution results in decrease in people's group behavior. In this plan, inappropriate furniture position (bench, kiosk, etc.) led to a decrease in people's willingness to stop and assemble in the space. (Pre-planning evaluation), furniture positioning must be done according to people's previous behavioral patterns and reformation of previous deficiencies and shortage.

Secure movement of users, especially in sidewalks, taking into account the assembly places, standing places or any other areas where people's assembly and ensuing interactions are of great importance. (pre-planning and planning and post-planning evaluations ), predicting the impacts of the plan on people, predicting feasible or certain changes in people's behavioral patterns, and providing initial necessary facilities for people to utilize and encourage them pause in the space.

After implementing the plan, the initial evaluation was set to two-year time period, to be followed for the next ten years in order to identify and determine the potential and possible impacts on the users of space, with the provision of a complete and prioritized framework for plan. Evaluation and analysis of the results were needed, to determine a pattern for analysis with the intention of carrying out environmental improvement and renovation plansin order to enhance the utility of the space as a unified space, which could be subsequently copied in other urban spaces, across the country.

\section{CONCLUSION}

The renovation of Sepah Street has had the following significant effect on users' behavior:

- In the morning, the prominent psychological atmosphere in the place is dominated by the seasonal workers' stressful behavior, and likewise, the shopping women at bazaar behave in the same manner.

- Due to the fact that renovated Sepah Street has limited places for resting and elderly gathering, the number of old people attending the place has fallen, dramatically. On the contrary, more youths are wandering around in this place. Therefore, it could be said that this project has been more successful in attracting youngsters.

- These modifications have not significantly affected the social class of the space users.

- Utilization of inappropriate materials has rendered the furniture unsuitable to use, particularly in winter.

- The main obstacles in the sidewalk before and after the project implementation, have hitherto been shop stuffs and infringement of car owners, respectively.

\section{REFERENCES}

[1] J. Lang, Creating Architectural Theory (The Role of the Behavior Science in Environmental Design), Van No strand Rein board p. 97, 1987.

[2] N. Barati, Language, Thought and Space: An introduction into the Post Modern Built Environment Ideas, ranian Municipalities Organization, pp. 60-63, 2003.

[3] J. Lang, Creating Architectural Theory (The Role of the Behavior Science in Environmental Design), Van No strand Reinboard, pp. 73-78, 1987.

[4] Sh. Mortazavi, Environmental Psychology and Its Applications, Shahid Beheshti University, pp. 1-3, 2001

[5] J. Pakzad, Theory and Process of Urban Design, Tehran, Shahidi, pp. 51-56, 2007.

[6] I. Altman, The Environment and Social Behavior: Privacy, Personal Space, Territory and Crowding, Monterey, CA: Brooks, Ch.11, pp. 251-260, 1975.

[7] M. Carmona, T. Heath, T. Oc, and S. Tiesdell, Public Places Urban Spaces: The Dimensions of Urban Design, (2nd ed.) London: Architectural Press, pp. 92, 2003.

[8] K. H. Karik, The Assessment of Places, in: Advances in Psychological Assessment, Palo Alto, CA: Science and Behavior Books, Ch 2, .pp. 45, 1971.

[9] M, Carmona, T. Heath, T. Oc, and S. Ties dell, Public Places Urban Spaces: The Dimensions of Urban Design, 2nd ed., London: Architectural Press, Ch.2,pp. 128, 2003.

[10] Bahraini, Analysis of Urban Spaces, Tehran University, pp. 106-108, 2007.

[11] M. Carmona, T. Heath, T. Oc, and S. Ties dell, Public Places Urban Spaces: The Dimensions of Urban Design, 2nd ed., London: Architectural Press, Ch. 2,pp. 137-142, 2003.

[12] I. Altman, The Environment and Social Behavior: Privacy, Personal Space, Territory and Crowding, Monterey, CA: Brooks, Ch.11, pp. 260-278, 1975.

[13] J. Lang, Creating Architectural Theory (The Role of the Behavior Science in Environmental Design, Van No strand Rein board, Ch.3, pp28-32, 1987. 
A. N. Barati was born in Tehran, Iran in 1955 . He received his master degree in urban planning from the University of Tehran in 1988. He received his PH.D in Urban Design from Edinburgh College of Art, Heriot-Watt University, U.K. in 1997.

He has been an academic member of staff, Department of Urban Planning Faculty of Architecture and Urbanism since 2001, and was the dean of the Faculty of Architecture and Urbanism (2007 - 2009), Imam Khomeini International University,

He wrote more than 5 books, 10 Published Articles and has done 6 Academic Activities \& Experiences.

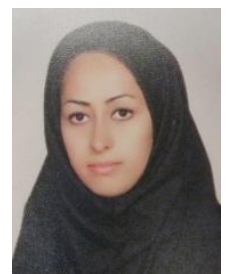

B. N. Falah was born in Qazvin, Iran on 21 October, 1988. She received her bachelor and master degree in urban planning from Imam Khomeini International University (IKIU) of Qazvin, Iran in 2010 and 2013 respectively.

She works as a researcher in IKIU Urban Planning research center in Qazvin and as a master in Shal Azad Islamic University.

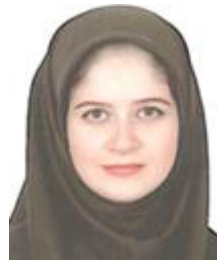

C. M. Piroozgar was born in Tehran, Iran on 22 April. She received her bachelor and master degree in urban planning from Imam Khomeini International University (IKIU) of Qazvin, Iran in 2010 and 2013 respectively.

She works as a researcher in IKIU Urban Planning research center in Qazvin. 